\title{
OPTIMAALSUSTEOORIA FONOLOOGIAS
}

\author{
Külli Prillop \\ Tartu Ülikool
}

Kokkuvõte. Optimaalsusteooria (OT) esitasid 1990. aastate alguses Alan Prince ja Paul Smolensky. Praeguseks on OTst saanud enim kasutatav teooria fonoloogias. Tegemist on generatiivse teooria edasiarendusega. Artiklis tutvustan lühidalt optimaalsusteooria põhiseisukohti, samuti mõningaid varasemaid teooriaid, mis on OTga seotud. Pööran tähelepanu ka sellele, miks OTs on nähtud funktsionalistide ja formalistide lepitajat, ning milliseid muutusi uurimisprobleemide valikul on OT levik kaasa toonud. Väiteid ilmestab lihtne näide eesti keele kaasaütleva käände kujunemisest: miks on tunnuseks kujunenud $-g a$, mitte - $k k a$ ega $-k s$.

Märksõnad: Optimaalsusteooria, fonoloogia, kaasaütlev kääne, funktsionalism, formalism, gemineerumine, nõrgenemine

\section{Sissejuhatus}

Generatiivse fonoloogia standardne teooria veel 1990ndate alguses oli SPE. Ingliskeelses kirjanduses tavaline lühend SPE tähistab Noam Chomsky ja Morris Halle 1968. aastal ilmunud tööd "The Sound Pattern of English", kus esitatakse Chomsky varasema transformatiivse süntaksiteooriaga sarnane transformatiivne fonoloogiateooria. Enamik praeguseid uurimisartikleid aga rakendavad optimaalsusteooriat (lühendatult OT), mille esimese versiooni esitasid 1990. aastate algul Alan Prince ja Paul Smolensky (1993/2004). Lühidalt öeldes on OT generatiivse grammatika edasiarendus, mis on täielikult loobunud tuletusreeglitest. Muud tähtsamad generativistide põhimõtted kehtivad aga ka OT-s: eristatakse süvavorme ja pindvorme; soovitakse kindlaks teha, mis on maailma keeltes ühist ja millised keeleteadmised on sünnipärased. OT on grammatika mudel, st kasutatav nii fonoloogias, morfoloogias, süntaksis kui ka semantikas ja pragmaatikas. 
Praeguseks, 20 aastat pärast OT sündi, on õigem rääkida OT-st kui üldisest raamistikust, sest on kujunenud väga palju alamteooriaid. Pole olemas ühtset OT-d, mida kõik uurijad pooldaksid. Peaaegu iga OT põhiväidet on erinevates alamteooriates kahtluse alla seatud. Kuigi OT pole enam ühtne teooria ja võibolla varsti esitatakse taas mõni päris uus generatiivne grammatikamudel, näitab praegust OT mõjuvõimu ilmekalt, et umbkaudu $3 / 4$ tähtsamates fonoloogiaajakirjades ilmunud artiklitest rakendab just seda teooriat (de Lacy 2007: 29), raamatute pealkirjades ei peeta enam vajalikuks mainida, et kasutatakse OT-d, ja ingliskeelsed OT-artiklid ei alga enam üldise teooriatutvustusega.

Teine silmatorkav muutus generatiivses fonoloogias on olnud nihe formalistlikust kontseptsioonist funktsionalistlikuma poole: erinevaid nähtusi seletades apelleeritakse aina rohkem artikulatoorsele pingutusele, tajumislihtsusele ja ökonoomiale. Funktsionalistlikke ideid rakendatakse algusest peale ka OT-s.

Eesti keeles on OT põhiväiteid ja mõningaid edasiarendusi sarjas „Teoreetiline keeleteadus Eestis” varem tutvustanud Karl Pajusalu (2002) ning Keeles ja Kirjanduses Külli Prillop (2006). Põhjalikumaks tutvumiseks sobivad ingliskeelsed õpikud: Kager (1999), McCarthy (2002 ja 2008).

Käesolevas artiklis esitan veel kord lühidalt standardse OT põhimõtted. Eesmärgiks on näidata, kuidas ühe ja sama nähtuse kirjeldamine erinevate teooriate abil lisab huvitavaid vaatenurki ja tõstatab uusi uurimisküsimusi. Lühitutvustusele ja rakendusnäitele järgnevate peatükkide sihiks pole aga mitte niivõrd OT enese esitlus, vaid kirjeldada seda teoreetilist tausta, milles OT kujunes ja areneb, pöörates tähelepanu eelkõige seostele funktsionalismiga.

\section{Optimaalsusteooria põhiseisukohad. Rakendus- näide.}

OT rakendamist fonoloogias, selle eeliseid ja ka probleeme kirjeldan eesti keele grammatisatsiooni kuldnäide, komitatiivi tunnuse kujunemise abil. Kogu kujunemisahela on Helle Metslang (2002: 164) esitatud järgnevalt: kansak $>k a \bar{s} a k>k \bar{a} s a$ ? $>$ 
$k \bar{a} s a>k \hat{a} s>k a s>-k a>-G a$. Grammatiseerumise uurijate jaoks ei ole kuigi oluline, kas vormist kâs kujunes järgmisel etapil kas või $k \bar{a}$ (eesti vana kirjakeele näited toetavad pigem teist varianti), või kas üksiku fortisklusiiliga algav $-k a$ ikka sai ilma leenistumata liituda vokaallõpulisele tüvele. Oluline on, et algne iseseisev sõna muutus järjest lihtsamaks ja lühemaks ning tähendus muutus järjest üldisemaks, st vabast sõnaühendist sai perifrastiline vorm, sellest liitvorm, hiljem morfoloogiline vorm.

Keeleajalugu uuriva fonoloogi jaoks on see siiski ainult osa arenguloost. $n$-i assimileerumine, sõnalõpulise $k$ (?) kadu ja lõpukadu olid eesti keele erinevatel arenguetappidel tavalised muutused, mis hõlmasid kõiki sõnu, mitte ainult grammatiseerumisprotsessis osalejaid, nt *kansi $>$ *kāsi (nagu *kansak $>$ *kāsak), *kenne? > kẹne (nagu *kāsa? > *kāsa), *kāsi > kâs (nagu *kāsa $>$ kâs). (Nende muutuste OT-analüüsi vt Prillop 2011.)

$G a$-lõpulise komitatiivi tekke kirjeldamisel on kõigepealt oluline täpsustada kaassõna kokkuhääldamise võimalust eelneva noomeniga. Eespool esitatud *kansak >> -Ga grammatiseerumisahelast võib jääda ekslik mulje, et tulevase käändelõpu liitumine eelneva noomeniga oli võimalik alles siis, kui *kansak oli redutseerunud $k a$-ks. Tegelikult kirjutab Huno Rätsep oma ajaloolise morfoloogia õpikus, et „pärast põhisõna lõpul oleva genitiivi $n$-i kadu hakkas kaassõna ilmselt tihedamini liituma põhisõnaga ja allus selles seoses lauserõhutus asendis mitmesugustele reeglipäratutele muutustele, kõigepealt kadus selle postpositsiooni lõpult $s$ ". (Rätsep 1979: 78) Et põhisõnaga võis mõnikord liituda juba kaas, tõendavad vana kirjakeele näited ('+’ tähistab kokkukirjutust, lausekatked TÜ vana kirjakeele korpusest http://www.murre.ut.ee/vakkur/Korpused/):

Terwütewt Maria, Yßant $\beta \mathrm{w}+$ kas. (Kullamaa käsikiri, 1524) eth tæma meidt oma Ißa+kaas erra+leppitanuth on (Müller, 1604) ninck lasckwat hend paliu tutta oma toiwutuße+kaas (Müller, 1605)

Niisuguseid kokkukirjutusi ei ole palju (vt täpsemalt Habicht 2000: 43-48) ja neid võiks pidada juhuslikeks kirjavigadeks, mitte tegeliku keelekasutuse peegelduseks (vanad autorid 
järgisid sageli pigem kujunenud kirjatraditsiooni kui rahvakeelt), kui sarnane nähtus oleks täiesti võõras praeguses eesti keeles. Sõna kaas liitumine eelneva noomeniga mitusada aastat tagasi on aga väga sarnane tänapäeva keelega, kus mitmed postpositsioonid võidakse samuti hääldada eelneva sõnaga kokku. Sageli soovib keelekasutaja kaassõna eelneva nimi- või asesõnaga isegi kokku kirjutada, tuues muu hulgas põhjenduseks kokkuhäälduse (vt Habicht, Penjam 2007). Muidugi leiab niisuguseid noomeni ja postpositsiooni kokkuhääldamisi hulgaliselt murdetekstidest, kusjuures pearõhk võib olla ka kaassõnal. Näiteks kõrgkooliõpikus „Eesti murded ja kohanimed” esitatud tekstinäiteis esinevad kä̈_ Bärast /käe pärast/, lumè_Bi·àle /lume peale/ (keskmurre); pe·rve ala /perve alla/, ke zä̈_Bül / kesa peal/ (Tartu murre) jmt (vt Pajusalu jt 2002: 199, 210-211).

Taoliste kokkuhäälduste puhul eesti keeles vokaalidevaheline klusiil nõrgeneb, nagu oli näha juba esitatud murdenäidetest. Paul Ariste toob oma foneetikaõpikus välja veel järgmised näitesõnad: käèGiri, vanàBoi $\Upsilon_{S}^{\prime}$, vanàDäDi (Ariste 1966: 118). Nagu ikka täiendavas jaotumuses olevate allofoonide puhul, ei ole lingvistilise hariduseta keelekõnelejad klusiili nõrgenemisest selles positsioonis teadlikud, mistõttu kirjalikes tekstides esineb ikka tugev klusiil.

Niisiis, juba 17. sajandil võis kaas mõnikord liituda eelneva sõnaga ning tõenäoliselt vokaalide vahele jäänud $k$ sel juhul nõrgenes. Mida tihedamalt postpositsioon eelneva sõnaga liitus, seda selgem oli nõrgenemine. Olenevalt kontekstist võidi öelda kord emà kâs, kord emà _Gâs. (Vokaalidevaheliste fortisklusiilide üldine nõrgenemine oli eesti keeles lõpule jõudnud 16. sajandiks (Alvre 1991: 243)). Lõplik muutus $k>G$, nii et varieerumine polnud enam võimalik, toimus aga alles siis, kui - $G a$ oli kujunenud käändelõpuks ega saanud enam iseseisva sõnana esineda.

Iga häälikumuutuse puhul võiks küsida, miks see muutus on toimunud ja millistel tingimustel. Miks ikkagi on tänapäevaseks vormiks just karuGa, aga mitte karuk $\breve{k} a$, kuigi sõnaalgulise klusiili gemineerumine sagedastes liitsõnades on eesti keeles (või vähemalt osas murretes) tavaline, nt võidakse öelda nii

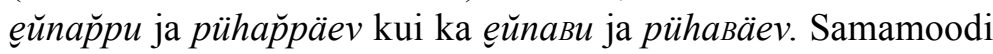


oleks võinud klusiil gemineeruda sõna kaas alguses. On huvitav, et taoline geminatsioon näibki olevat toimunud Lõuna-Eestis, kus kohati esineb komitatiivi lõpp - $\breve{k k a}$, nt Põlva lašte $\breve{k} k a$, Otepää kätť ̌̌kka (Rätsep 1979: 80). Pealegi, mitmed varem kujunenud sufiksid algavad geminaadiga, mitte üksikklusiiliga, nt ilmaütleva käände tunnus, mitmuse 2. pöörde lõpp. Järgneva analüüsi eesmärgiks pole siiski esitatud probleemi ammendav lahendus, vaid OT metoodika tutvustamine.

OT grammatikal on kolm komponenti: leksikon, generaator ja hindaja (Kager 1999: 18-25). Generaatori ülesandeks on antud sisendist (leksikonis talletatud süvavormist) kõikvõimalike väljundikandidaatide genereerimine. Umbes 17. sajandil, kui komitatiivi tunnus ei olnud veel välja kujunenud, võis leksikonis olla postpositsioon kaas (või kaa või kas; see erinevus pole vokaalidevahelise klusiili nõrgenemise seisukohalt oluline). Leksikoni vormid põhinevad parasjagu käibivatel väljundvormidel. (OT ei ole keeleajaloo teooria, aga igat keeleajaloo perioodi saab vaadelda sünkroonselt.) Liites kaas näiteks sõnale karu, moodustaks generaator teoreetiliselt lõpmatu väljundikandidaatide loendi karu kaas, karukaas, karukkaas, karugaas, karuks, .... Generaator töötab piiranguteta ja on universaalne selles mõttes, et ühesuguse sisendi puhul genereeritakse alati samad väljundikandidaadid, keelest sõltumata (McCarthy 2002: 8-10).

Hindaja ülesanne on väljundikandidaatide seast parima valimine. Sellest parimast ehk optimaalsest kandidaadist saabki tegelik väljundvorm. Optimaalse kandidaadi valimisel kasutab hindaja universaalsete kitsenduste hierarhiat. Eksisteerivad näiteks kitsendused *VTV 'vokaalidevaheline klusiil ei ole helitu' ja *GeminaAt 'geminaate ei ole'. Need on markeerituskitsendused (markedness constraints). Markeerituskitsenduste ülesanne on nõuda või takistada teatud segmentide kasutamist väljundvormides. Markeerituskitsendused „näevad” ja hindavad ainult väljundvormi, sisendit nad arvesse võtta ei saa. Markeerituskitsendustelevastanduvadustavuskitsendused (faithfulness constraints), mis keelavad sisendvormi muuta. Näiteks, karuks rikub ustavuskitsendust, mis keelab sisendist segmente ära jätta; karugaas ja karugaas aga rikuvad ustavuskitsen- 
dust, mis nõuab sisendi helitu segmendi helitust ka väljundis (IDENTNE[-heliline]).

Standardse OT järgi kasutavad kõikide keelte grammatikad ühtesid ja samu kitsendusi ja kõik kitsendused on olemas kõikide keelte grammatikates. Keeled erinevad vaid kitsenduste olulisuse poolest ja keele muutumine tähendab kitsenduste ümberpaiknemist hierarhias. (Prince, Smolensky 1993/2004: 1-6, Kager 1999: 4, McCarthy 2002: 13-14)

Optimaalse kandidaadi valikut kirjeldavad OT-tabelid (vt tabel 1). Tabelitesse ei mahu muidugi ei kõik kandidaadid ega ka kõik kitsendused. Analüüsides esitatakse vaid analüüsitava nähtuse seisukohalt olulised kandidaadid (esimeses veerus) ja kitsendused (veergude päistes). Optimaalse vormi valikul kontrollitakse kõigepealt, millised kandidaadid rahuldavad hierarhia tipus olevat kitsendust. Seejärel, jättes kõrvale ülejäänud, kontrollitakse, millised kandidaadid rahuldavad hierarhias järgmist kitsendust. Nii toimitakse, kuni alles on jäänud ainult üks kandidaat, millest saabki tegelik väljundvorm. Tabelis on kitsenduste rikkumised märgitud tärnidega. Kui rikkumine saab kandidaadile saatuslikuks, on tärni järel hüüumärk ja järgnevad lahtrid vastavas reas halli taustaga. Valitud väljundvormi tähistab ${ }^{\circ}$. Selliselt vormistatud tabelid on OT kirjanduses traditsioonilised.

Tabel 1. /karu+kaas/ $\rightarrow$ karuGaas

\begin{tabular}{|l||l|l|l|}
\hline Sisend: $/$ karu+kaas/ & $*$ VTV & *GEMINAAT & $\begin{array}{l}\text { IDENTNE } \\
{[- \text { heliline }]}\end{array}$ \\
\hline a. $\quad$ karukaas & $* !$ & & \\
\hline b. $\quad$ karukkaas & & $* !$ & \\
\hline c. $\quad$ karugaas & & & $*$ \\
\hline
\end{tabular}

OT on väga võimas teooria selles mõttes, et väljundikandidaatide hulk on piiramatu, st ka markeeritud struktuuride parandamiseks on piiramatult võimalusi. Samas on teooria ka väga piiratud. Iga analüüs tähendab sobiva kitsenduste hierarhia leidmist, aga täpselt sama hierarhia peab kehtima ka uuritava keele kõikides muudes osades. Iga üksiknähtuse analüüs viib 
suure hulga erinevate prognoosideni. Niisiis on teooria kehtivuse testimisel olulised just ulatuslikud üheainsa keele grammatika analüüsid. Niisuguste analüüside teostamise raskust näitab nende üliväike osakaal kõigi OT-analüüside hulgas.

Tabelis 1 esitatud analüüs ei sobi tegelikult eesti keele jaoks, sest sellise hierarhia korral kaoks väljundvormidest kõik geminaadid, nt poleks väljundiks mitte ilma karutta, vaid ilma karuDa, vt tabel 2. Märk $:$ pannakse faktidega vastuolus oleva võitja-kandidaadi ette.

Tabel 2. $/ \mathrm{karu}+\mathrm{tta} / \rightarrow * k a r u d a$

\begin{tabular}{|l|l|l|l|l|}
\hline \multicolumn{2}{|l|}{ Sisend: /karu+tta/ } & *VTV & *GEMINAAT & $\begin{array}{l}\text { IDENTNE } \\
{[- \text { heliline }]}\end{array}$ \\
\hline a. & karuta & $* !$ & & \\
\hline b. & karutta & & $* !$ & \\
\hline c. $: 0$ & karuda & & & $*$ \\
\hline
\end{tabular}

Analüüsi päästaks ustavuskitsendus SÄILITA-geminaat 'sisendi geminaat on ka väljundis geminaat', vt tabel 3 .

Tabel 3. $/ \mathrm{karu}+\mathrm{tta} / \rightarrow$ karutta

\begin{tabular}{|l||l|l|l|l|}
\hline $\begin{array}{l}\text { Sisend: / } \\
\text { karu+tta/ }\end{array}$ & $\begin{array}{l}\text { SÄILITA- } \\
\text { geminat }\end{array}$ & *VTV & *GEMINAAT & $\begin{array}{l}\text { IDENTNE } \\
{[- \text { heliline }]}\end{array}$ \\
\hline a. karuta & $* !$ & $*$ & & \\
\hline b. karutta & & & $*$ & \\
\hline c. karuda & $* !$ & & & $*$ \\
\hline
\end{tabular}

Paraku, sellise hierarhia korral ei ole kuidagi võimalik väljundvorm pühappäev, vaid ainult pühaвäev (tabel 4). Kui oletada, et mõnes murdes siiski olid samaaegselt võimalikud pühappäev ja karugaas, tuleks hierarhiat veelgi täiendada. Kitsendus *GeminaAt peab jääma kõrgemale kui Identne[-heliline], sest muidu oleks väljundiks karukkaas, vt tabel 1, ja *VTV peab jääma kõrgele, sest see tekitab eesti keelele iseloomulikud poolhelilised klusiilid. 
Tabel 4. /püha+päev/ > pühaвäev

\begin{tabular}{|l|l|l|l|l|}
\hline $\begin{array}{l}\text { Sisend: / } \\
\text { püha+päev/ }\end{array}$ & $\begin{array}{l}\text { SÄILITA- } \\
\text { geminaat }\end{array}$ & $*$ VTV & $*$ GEMINAAT & $\begin{array}{l}\text { IDENTNE } \\
{[- \text { heliline }]}\end{array}$ \\
\hline a. püha.вäev & & & & $*$ \\
\hline b. püha.päev & & $* !$ & & \\
\hline c. pühap.päev & & & $* !$ & \\
\hline
\end{tabular}

Üheks lahendusvõimaluseks oleks võtta kasutusele positsiooniline ustavuskitsendus (positional faithfulness constraint), mis seob [-heliline] säilitamise nõude sõna pearõhuga: IDENTNE[-heliline]/б. Sel juhul nõrgeneks klusiil liitsõna teise osise algul ainult sel juhul, kui teine osis ei kanna enam sõna pearõhku, kusjuures pearõhu säilitamiseks täistähenduslikes sõnades oleks vaja jällegi omaette ustavuskitsendust.

Esitatud näitest on ilmne, et lihtsam on teostada väikese hulga üksiknähtuste analüüsi erinevates keeltes kui ühe keele terviklikku analüüsi. Kui varem oli teadlane mingi keele või keelte grupi asjatundja, siis pärast OT levikut on teadlane pigem mingi nähtuse asjatundja. Vokaalidevaheliste klusiilide helilisuse muutumist erinevates keeltes on OT abil uurinud näiteks Robert Kirchner (2004) ja Jennifer Smith (2008). Vokaalidevahelise klusiili gemineerumine on harvaesinev nähtus, v.a rõhulise silbi pikendamiseks. Siiski, näiteks malajalami inglise keeles gemineeruvad helitud üksikklusiilid, et ära hoida nende heliliseks muutumist, st et võimendada helilisuskontrasti. Nt packet hääldub [pæækket], aga baboon hääldub [bææbuun], kusjuures neid vorme on analüüsitud sisuliselt samade kitsenduste abil, mida kasutasin eespool eesti keele jaoks. (Vt Mohanan, Mohanan 2003)

Tabelites 1 ja 2 kasutatud kolme kitsendust saab omavahel järjestada kuuel erineval moel. Kui kehtib hierarhia *VTV, *GeminaAt $\gg$ Identne[-heliline] ${ }^{1}$, on kõik vokaalidevaheli-

1 Märgist $\gg>$ vasakul olev kitsendus domineerib paremal oleva üle; koma on nende kitsenduste vahel, mille omavaheline järjestus pole kirjeldatava nähtuse jaoks oluline. 
sed üksikklusiilid helilised nagu malajalami keeles, hierarhia IDENTNE[-heliline], *GEMINAAT $>$ *VTV korral võivad vokaalidevahelised üksikklusiilid olla nii helilised kui ka helitud (leksikaalsed kontrastid säilivad) nagu inglise keeles. Hierarhia *VTV, IdEnTnE[-heliline] > * GeminaAt kehtib aga malajalami inglise keeles, kus vokaalidevahelised helitud üksikklusiilid gemineeruvad. (Mohanan, Mohanan 2003) Niisugust üksikute, teatud nähtuse kirjeldamisel vajalike kitsenduste järjestamise kõikvõimalike variantide esitust nimetatakse osaliseks tüpoloogiaks (factorial typology) ja kasutatakse, et kontrollida kitsenduste sobivust. Ükski võimalik hierarhia ei tohiks tekitada selliste omadustega keelt, mida ei saa olemas olla. (Prince, Smolensky 1993/2004: 105-118)

\section{OT põhiväidete seosed varasemate keeleteooriatega}

Noam Chomsky jaoks oli grammatika eesmärk kirjeldada inimese keelekompetentsi ehk seda, mida kõneleja teab oma keelest. Eesmärk oli minna üksikkeelte uurimisest edasi ja leida, mis on inimkeele universaalsed, bioloogiliselt kaasasündinud omadused. Chomskylik generatiivne fonoloogia on segmentaalne, reeglipõhine ja derivatiivne. Fonoloogilise representatsiooni põhielement on häälik ehk segment, mis koosneb universaalsetest ja distinktiivsetest tunnustest, nt $t$ on [+koronaalne, -heliline, ...]. Reegel kirjeldab sisendit ja määrab, kuidas seda muuta. Reeglid on keelespetsiifilised ja neid rakendatakse üksteisele järgnevalt. (McCarthy 2002: 48)

Generatiivse fonoloogiaga tegelejad panid tähele, et täiesti erinevad reeglid võivad omada ühist eesmärki: nt üks reegel rakendub teatud häälikujärjendi vältimiseks, teine jääb rakendumata, kui tekkiks seesama järjend (McCarthy 2002: 53). Sellist nähtust hakati nimetama konspiratsiooniks. Tuntuim konspiratsiooninäide on jokuti keelest (Yawelmani Yokuts, indiaanikeel Californias), kus on mitu reeglit, mis hoiavad ära kolme konsonandi järjendid, nt: 


$$
\begin{array}{ll}
\varnothing \rightarrow \mathrm{i} / \mathrm{C}_{-} \mathrm{CC} & \begin{array}{l}
\text { 'lisa kolme konsonandi järjen- } \\
\text { disse } i \text { ' }
\end{array} \\
\mathrm{V} \rightarrow \varnothing / \mathrm{VC} \_\mathrm{CV} & \text { 'kaota vokaal, millele eelneb ja } \\
& \text { järgneb üksikkonsonant' (St, } \\
& \text { vokaal ei kao, kui eelneb või } \\
& \text { järgneb konsonantühend, sest } \\
& \text { siis tekkiks kolme konsonandi } \\
& \text { järjend.) }
\end{array}
$$

Sarnane nähtus eesti keeles on I või II vältes ühesilbiliste sisusõnade vältimine. Morfoloogiakirjelduses võib (lihtsustatult) öelda, et nominatiivi vorm moodustatakse genitiivi lõpuvokaali ära jättes, kui sõna esimene silp on pikk, nt kooli $\rightarrow$ kool (aga mitte $\left.n a g i \rightarrow{ }^{*} n a g\right)$. Samas, CVC struktuuriga inglise laensõnade lõppu lisatakse vokaal, nt $p u b \rightarrow$ pubi. Täiesti erinevate reeglite koostöös välditakse teatud struktuure, kusjuures puudub formaalne võimalus nende reeglite seostamiseks.

Probleemi lahendamiseks võeti kasutusele kitsendused (Kisseberth 1970). Jokuti reegli V $\rightarrow \varnothing /$ VC__CV sai nüüd asendada reegliga $\mathrm{V} \rightarrow \varnothing / \mathrm{C}_{-} \mathrm{C}_{\mathrm{C}}$ ja kitsendusega $* \mathrm{CCC}$. Kitsendus *CCC kutsub esile $i$ epenteesi reegli rakendumise ja blokeerib V kao reegli rakendumist, lihtsustades sel moel grammatikat ja seostades need protsessid.

Kasutusele võeti morfeemistruktuuri kitsendused, mis määrasid, millised on lubatud süvavormid; ja ka pindstruktuuri kitsendused. Muidugi tekitas kitsenduste laialdane kasutamine ka uusi probleeme. Näiteks, mis saab, kui üks kitsendus blokeerib reegli rakendumist, aga teine kitsendus nõuab sellesama reegli rakendumist - kas kitsendustel on erinevad prioriteedid? Või mis juhtub, kui kitsenduse rahuldamiseks sobivad mitu erinevat reeglit - kas reeglitelgi on prioriteedid? Kas enne reegli rakendamist peaks kontrollima, et see vähendab kitsenduste rikkumist? Oli tekkinud „kontseptuaalne kriis”, mille lahendamiseks pakkusid Prince ja Smolensky välja OT. (Vt Prince, Smolensky 1993/2004: 1-4.)

Samal ajal hakati ka küsima, kuidas generatiivses teoorias paremini käsitleda loomulikke protsesse. Generatiivses fonoloogias peeti loomulikumateks niisuguseid reegleid, mis hõlmavad 
vähem tunnuseid. Niisugused reeglid arvati olevat esindatud rohkemates keeltes. Kui reeglite loomulikkust hinnata ainult tunnuste hulga järgi, tekkib jällegi tõsine teoreetiline probleem. Nimelt, reeglite vastupidiseks pööramine (neis tunnuste vastasmärgiliseks muutmine) peaks andma sama loomulikud reeglid (tunnuste hulk ei muutu), ometi see nii pole. (McCarthy 2002: 49)

David Stampe (1979) jõudis järeldusele, et generatiivne lähenemine, mille järgi lapsed keelt omandades omandavad reeglid, ei sobi faktidega. Näiteks saksa keeles on kõik sõnalõpulised klusiilid helitud, inglise keeles mitte. Teooria järgi peaks saksa lapsed omandama klusiilide helituks muutmise reegli. Tegelikult on vastupidi: saksa lapsed ei õpi sõnalõpu klusiile heliliselt hääldama. Inglise lapsed seevastu hääldavad sõnalõpu klusiile esialgu helitult, nagu saksa lapsedki, hiljem järk-järgult „unustavad" selle tendentsi. Niisugune lähenemine fonoloogilistele protsessidele viis loomuliku fonoloogia (Natural Phonology) väljaarendamiseni.

Loomuliku fonoloogia keskne idee on, et eksisteerivad sünnipärased loomulikud protsessid nagu sõnalõpu klusiilide helituks muutumine ja vokaalidevaheliste üksikklusiilide heliliseks muutumine. Keele omandamise alguses on kõik need loomulikud protsessid aktiivsed, nii et laste varased ütlused on markeerimata. Keele omandamine tähendab nende protsesside täielikku või osalist pärssimist. Loomulikud protsessid vähendavad leksikaalseid erinevusi, st tekkib võitlus häälduslihtsuse ja selguse vahel (Stampe 1979). See idee on üsna lähedane OT ideele markeeritusja ustavuskitsenduste võitlusest. (McCarthy 2002: 50-52)

\section{Funktsionalistlikud markeerituskitsendused}

Prince ja Smolensky ei väitnud kitsenduste olemuse kohta eriti rohkemat, kui et need on lihtsad ja üldised ning Universaalse Grammatika osa (Prince, Smolensky 1993/2004: 1-9). OT standardne eeldus on, et kitsendused on kaasasündinud, st et keele omandamisel laps alustab mingisuguse sünnipärase hierarhiaga (Tesar, Smolensky 1998: 237). Nii ulatuslikust sünni- 
pärasest teadmiste hulgast ei unistanud ilmselt isegi Chomsky. Paljud OT kasutajad on kitsenduste sünnipärasuse ideest loobunud ja otsivad teisi võimalusi.

Juba esimeses OT õpikus kirjutab René Kager (1999: 11), et fonoloogilised markeerituskitsendused peaks olema ka foneetiliselt põhjendatud. Võimalus ühendada OT ja funktsionalism oli selge juba OT algusest. (Funktsionalism ei ole fonoloogias uus idee. See algab Ferdinand de Saussure'i ning tema õpilastega.) Funktsionaalselt põhjendatud kitsendustega OT on praeguseks leidnud palju poolehoidjaid (nt Kaun 1995, Hayes, Steriade 2004 jpt, vt ka ülevaadet Gordon 2002). Eeldatakse, et markeeritud segmendid, mida kitsendused keelavad, on foneetiliselt keerukad ja/või raskemini tajutavad. Ptk 2 analüüsinäites kasutatud kitsendus *VTV on põhjendatud sellega, et vokaalidevahelise klusiili hääldamisel on õhuvoolu katkestav sulg nii lühiajaline, et häälekurdude võnkumine ei jõua tajutavalt lakata, kui kõneleja ei tee selleks lisapingutusi (vt Westbury, Keating 1986: 149-152). Kitsendus *GeminaAt on selle lisapingutuse vastu, mida peab tegema geminaadi hääldamisel.

Foneetiliselt põhjendatud kitsendustega optimaalsusteoorias ei ole vaja eeldada, et kitsendused on kaasasündinud. Kuna keele omandaja saab oma kogemustele tuginedes hinnata foneetilist keerukust, on ta võimeline ise kitsendusi tuletama. Universaalne Grammatika ei ole sel juhul mitte a priori kitsenduste hulk, vaid kitsendused konstrueeritakse mehhanismide poolt, mis mõõdavad häälduslihtsust ja tajulihtsust. (Hayes, Steriade 2004: 6-7) Kitsenduste foneetilise põhjendamise nõudest kaugemale minevaid funktsionalistlikke lähenemisi on OT raamistikus mitmeid. Üht neist on eesti keeles põgusalt tutvustanud Karl Pajusalu (2002: 206).

Väärib märkimist, et ka formalistlik lähenemine ei välista funktsionaalseid põhjendusi kitsendustele. Evolutsioon võib osa kitsendusi eelistada, sest need hõlbustavad info töötlemist, tekitades illusiooni, et kõigil kitsendustel peab olema funktsionaalne põhjendus. Formalistliku lähenemise erinevus on pigem selles, et kitsendustel võib olla arbitraarseid aspekte, st kitsendused ei pea tingimata lihtsustama hääldust ega tajumist. Näiteks pole lei- 
tud foneetilist põhjendust sonoorsusskaalale ( $a$ on kõige sonoorsem, järgnevad $e$ ja $\mathrm{o}$, siis $i$ ja $u$, siis $j$, siis $l$ ja $r$ jne), mida on erinevates analüüsides väga sageli kasutatud. Sonoorsusskaala näib olevat vähemalt osaliselt arbitraarne, s.t ilma funktsionaalse motivatsioonita. (Muidugi võib ka olla, et me ei oska õigest kohast otsida). Problemaatiline on ka toonist ja sonoorsusest sõltuv rõhk. Pikemad segmendid, nt pikad vokaalid ja diftongid, sageli tõmbavad enesele rõhku. See on funktsionaalselt põhjendatav. Pikemate segmentide parem sobivus rõhuga võib põhjustada ka rõhu nihkumist madala sonoorsusega vokaalidele, sest tüüpiliselt on need pikema omakestusega kui kõrgema sonoorsusega vokaalid. Kuid mitmes keeles (nt tai) on madalama tooniga vokaalid pikemad kui kõrge tooniga vokaalid. Kui madal toon pikendab kestust ja rõhk on eelistatult pikematel segmentidel, oleks funktsionaalselt põhjendatud ka rõhu nihkumine madala tooniga segmendile. Teadaolevalt ei ole nii mitte üheski keeles. Muidugi võib olla sellele mõni muu funktsionaalne põhjendus, kuid eeldades, et keeled erinevad selle poolest, millist funktsionaalset kitsendust nad tähtsaimaks peavad, on imelik, et teadaolevalt mitte ükski keel ei vii rõhku madala tooniga segmendile. Formalistliku lähenemise nõrkus pole mitte see, et tendentse ei põhjendata, vaid et raske on leida tõendeid. Me teame liiga vähe fonoloogilisest evolutsioonist. (de Lacy 2007: 28)

\section{Kokkuvõte}

Praeguste teadmiste juures ei ole võimalik öelda, kui hästi üks või teine lingvistikateooria kirjeldab inimese keelevõimet. Ei ole üht ainuõiget teooriat keele uurimiseks. Optimaalsusteooria (OT) on generatiivsest grammatikast väljakasvanud teooria, mida on arendatud ligi 20 aastat. OT-1 on seoseid ka paljude muude teooriatega. Eestikeelses kirjanduses on seni märkimata jäänud OT seos loomuliku fonoloogiaga.

OT olulisim väide on, et iga keele grammatika määrab universaalsete rikutavate kitsenduste hierarhia. See tähendab, et igas keeles kehtivad täpselt samad universaalsed printsiibid, 
kuid need on erinevates keeltes erineva tähtsusega. Nii on iga üksikkeele analüüs paratamatult seotud kõikide teiste keeltega. Näiteks, klusiili nõrgenemine vokaalide vahel on motiveeritud sama kitsendusega nii eesti kui ka mis tahes muus (nt malajalami) keeles.

OT aitab esile tuua keeltevahelisi sarnasusi, samuti omavahel siduda keeles aset leidvaid erinevaid protsesse. OT näeb keele grammatikat ühtse süsteemina. Väikegi muudatus grammatika ühes osas mõjutab kogu keelt. Näiteks ei ole võimalik mõne üksikprobleemi lahendamiseks tõsta hierarhia tippu geminaatide-vastast kitsendust niisuguses keeles, kus geminaadid muudel juhtudel eksisteerivad. OT-eelses generatiivses lingvistikas oli analoogne võimalus olemas, sest võis kasutada väga spetsiifilisi teisendusreegleid. Ulatuslike üheainsa keele analüüside tegemine on OT raamistikus küllalt keeruline, aga siiski huvitav ettevõtmine, sest võib esile tuua seni märkamata jäänud seoseid erinevate nähtuste vahel.

OT on aidanud ühendada funktsionaliste ja formaliste, vähemasti fonoloogias. Mitmed optimaalsusteoreetikud nõuavad, et kitsendused peavad olema foneetiliselt põhjendatud, st eelistama foneetiliselt lihtsamaid struktuure. Niisugused kitsendused ei pea olema kaasasündinud, vaid laps saab need keelt omandades ise tuletada. Funktsionaalselt põhjendatud kitsendustega OT on praeguseks laialt levinud, sest näib keeles toimuvaid protsesse paremini seletavat kui ainult tüpoloogiliselt motiveeritud kitsendustega OT. Formalistide arvates võib aga enamiku kitsenduste funktsionaalne põhjendatavus olla vaid evolutsiooni tekitatud illusioon.

Eestis on OT seni veel vähe tuntud. Kindlasti vääriks OT Eesti keeleteaduses senisest suuremat tähelepanu.

Aadress:

Külli Prillop

Eesti ja üldkeeleteaduse instituut

Tartu Ülikool

Jakobi 2, 51014 Tartu

E-mail: Kulli.Prillop@ut.ee 


\section{Kirjandus}

Alvre, Paul (1991) “Anmerkungen zum qualitativen Stufenwechsel mit besonderer Berücksichtigung der alten estnischen Schriftsprache". Linguistica Uralica 4, 241-249.

Ariste, Paul (1966) Eesti keele foneetika. Õpik Ajaloo-Keeleteaduskonna keeleosakondade üliõpilastele. Tartu: Tartu Riiklik Ülikool.

Chomsky, Noam, Morris Halle (1968) The sound pattern of English. Cambridge, Massachusetts: The MIT Press.

de Lacy, Paul (2007) “Themes in phonology”. In P. de Lacy, ed. The Cambridge handbook of phonology, 5-30. Cambridge: Cambridge University Press.

Gordon, Matthew (2002) "Functionalism in phonology". In P. de Lacy, ed. The Cambridge handbook of phonology, 61-78. Cambridge: Cambridge University Press.

Habicht, Külli (2000) “Grammaticalization of adpositions in old literary Estonian”. In M. Erelt, ed. Estonian: typological studies IV, 19-58. Tartu: University of Tartu.

Habicht, Külli, Pille Penjam (2007) „Kaassõna keeleuurija ja -kasutaja käsituses". Emakeele Seltsi aastaraamat 52, 51-68.

Hayes, Bruce, Donca Steriade (2004) "Introduction: the phonetic bases of phonological markedness". In B. Hayes, R. Kirchner, D. Steriade, eds. Phonetically based phonology, 1-33. Cambridge: Cambridge University Press.

Kager, René (1999) Optimality theory. Cambridge: Cambridge University Press.

Kaun, Abigail (1995) The typology of rounding harmony: an optimality theoretic approach. Doctoral Dissertation. University of California Los Angeles.

Kirchner, Robert Martin (2004) “Consonant lenition”. In B. Hayes, R. Kirchner, D. Steriade, eds. Phonetically based phonology, 313-345. Cambridge: Cambridge University Press.

Kisseberth, Charles (1970) "On the functional unity of phonological rules". Linguistic Inquiry 1, 291-306.

McCarthy, John J. (2002) A thematic guide to optimality theory. Cambridge: Cambridge University Press.

McCarthy, John J. (2008) Doing optimality theory. Blackwell Publishing.

Metslang, Helle (2002) „Grammatikalisatsiooniteooriast eesti keele taustal”. Rmt. R. Pajusalu, I. Tragel, T. Hennoste, H. Õim, toim. Teoreetiline keeleteadus Eestis, 164-178. Tartu: Tartu Ülikooli Kirjastus.

Mohanan, Tara, K. P. Mohanan (2003) "Towards a theory of constraints in OT: emergence of the not-so-unmarked in Malayalee English". $<$ http://roa. rutgers.edu/files/601-0503/601-0503-MOHANAN-0-0.PDF $>$. Vaadatud 15.08.2011.

Pajusalu, Karl (2002) „Varieerumisreeglid ja optimaalsusteooria”. R. Pajusalu, I. Tragel, T. Hennoste, H. Õim, toim. Teoreetiline keeleteadus Eestis, 195-208. Tartu: Tartu Ülikooli Kirjastus. 
Pajusalu, Karl, Tiit Hennoste, Ellen Niit, Peeter Päll, Jüri Viikberg (2002) Eesti murded ja kohanimed. Tallinn: Eesti Keele Sihtasutus.

Prillop, Külli (2006) „Optimaalsusteooria: kuidas eesti keeles klusiilid nõrgenesid ja kadusid". Keel ja Kirjandus 12, 955-972.

Prillop, Külli (2011) Optimaalsusteoreetiline käsitlus eesti keele fonoloogilisest kujunemisest. (Dissertationes philologiae Estonicae Universitatis Tartuensis, 28.) Tartu: Tartu Ülikooli kirjastus.

Prince, Alan, Paul Smolensky (1993/2004) Optimality theory: constraint interaction in generative grammar. Malden, MA: Blackwell.

Rätsep, Huno (1979) Eesti keele ajalooline morfoloogia II: Õpivahend eesti filoloogia osakonna üliõpilastele. Tartu: Tartu Riiklik Ülikool.

Smith, Jennifer L. (2008) "Lenition and fortition in optimality theory". In J. Brandão de Carvalho, T. Scheer, P. Ségéral, eds. Lenition and fortition, 519-560. Berlin, New York: Mouton de Gruyter.

Stampe, David (1979) A dissertation on natural phonology. New York: Garland.

Tesar, Bruce, Paul Smolensky (1998) "Learnability in optimality theory". Linguistic Inquiry 29, 229-268.

Westbury, John R., Patricia A. Keating (1986) "On the naturalness of stop consonant voicing”. Journal of Linguistics 22, 145-166.

\begin{abstract}
Külli Prillop: Optimality Theory in phonology. Optimality Theory (OT), which has become the dominant paradigm for phonological research, was developed in the early 1990s by Alan Prince and Paul Smolensky. Compared to rule-based frameworks, OT arguably has more explanatory power. OT also gives the opportunity for the synthesis of functionalist and formalist ideas. In this paper, I introduce some main principles of OT. To illustrate how OT works, I present a somewhat simplified case study of the phonological development of Estonian comitative ending - $g a$ (from the postposition *kansak 'with'). The aim of this paper is to introduce OT (in Estonian) to postgraduate students and researchers working within other theoretical frameworks.
\end{abstract}

Keywords: Optimality Theory, phonology, comitative, functionalism, formalism, germination, lenition 